\title{
STRUCTURAL ANALYSIS OF TOURISM EMPLOYEES \\ IN THE ROMANIAN SPA RESORTS
}

DOI: http://dx.doi.org/10.18509/GBP.2020.72

UDC: 338.488.2:640.412-057]:005.52(498)"2000/2018"

\author{
Alexandra Grecu ${ }^{1,2}$ \\ Karina Andreea Gruia ${ }^{1,2}$ \\ Bogdan Teriș ${ }^{1,2}$ \\ Andrei Ducman ${ }^{1,2}$ \\ Irina Rădoi ${ }^{1,2}$ \\ ${ }^{1}$ University of Bucharest-Research Center for Integrated Analysis \\ and Territorial Management; Bucharest, Romania \\ ${ }^{2}$ Faculty of Geography, University of Bucharest, Bucharest, Romania
}

\begin{abstract}
The tourism sector plays an important role in the economic development of the territorial systems that have spa resources, where one of its multiplier effects is the creation of jobs. The study aims to analyze the evolution of the number of employees from the tourism sector in the romanian spa resorts, which are in accordance with the Governmental Decision no. 926 of 2016, regarding the granting of the spa and balneoclimatic resort status for some localities and areas that have natural treatment factors.

The methodology consists of a series of statistical analyzes of the economic data for a period of 19 years, 2000-2018, which contains at the level of territorial administrative unit and at the level of 4-digit NACE code, the evolution of the tourism employees. The data series was subsequently used for creating evolution graphs and distribution maps for the tourism employees in the romanian spa resorts.

The results obtained present the contribution of the spa sector in creating jobs in the spa resorts and also the different reporting patterns in which these resorts are classified, according to the number and share of the tourism employees out of the total number of employees.
\end{abstract}

Keywords: tourism, employees, SPA resorts, structural analysis, Romania

\section{INTRODUCTION}

Today, tourism is considered as one of the largest generators of wealth and is classified as a major contributing factor to economic development [1], a priority sector for the Romanian economy [2]. Many tourism plans and policies state that tourism is a development option that is desired for communities, because its economic benefits will contribute both directly and indirectly to improving the welfare of the destination community [3]. Spa tourism, known worldwide as one of the oldest forms of tourism [4], generates a direct impact, through employment and income, as well as indirectly [5]. This spa tourism represents an economic component that has a spectacular dynamic, the integrated analysis of this sector being a key element in understanding the complex relationships [6], which offers sustainability to the local economies with such resources. At the level of Romania, spa tourism is a major type of tourism, due to its specific features and due to the fact that this country holds an important percentage of the mineral and thermal waters of Europe. The great advantage of tourism is that it tends to be intense in 
terms of labor, which means that an increase in output normally leads to an increase in employment. [7]. One of the important roles of the tourism sector is that it offers employment opportunities, opportunities to increase the foreign exchange reserves and also in the socio-economic development (an important contribution to economic prosperity) [8].

Being an important economic factor in terms of economic growth and job creation, tourism has more and more primary social need [9], [10], [11], [12], [13].

\section{METHODOLOGY}

In this study, 32 resorts from Romania were analyzed, which are in accordance with the Governmental Decision no. 926 of 2016, regarding granting the status of spa and balneoclimatic resort for some localities and areas that have natural treatment factors.

For these territorial systems that have spa resources, an economic database was created, both at the level of territorial administrative unit and at the level of four-digit NACE code (Classification of National Economy Activities), with the economic indicator considered relevant to the study, the number of employees from the tourism sector, for a period of 19 years, 2000-2018. Based on this, graphic representations were made that analyze the evolution of the number of employees in tourism and their share in the total economy as well as their evolution by activity areas (four-digit NACE codes). Also, cartographic representations were presented, showing the distribution at the level of resorts of the share of the number of tourism employees from the total economy. These maps, as well as the one showing the distribution of the spa resorts in Romania (Figure 1), were made with the help of open-source QGis software.

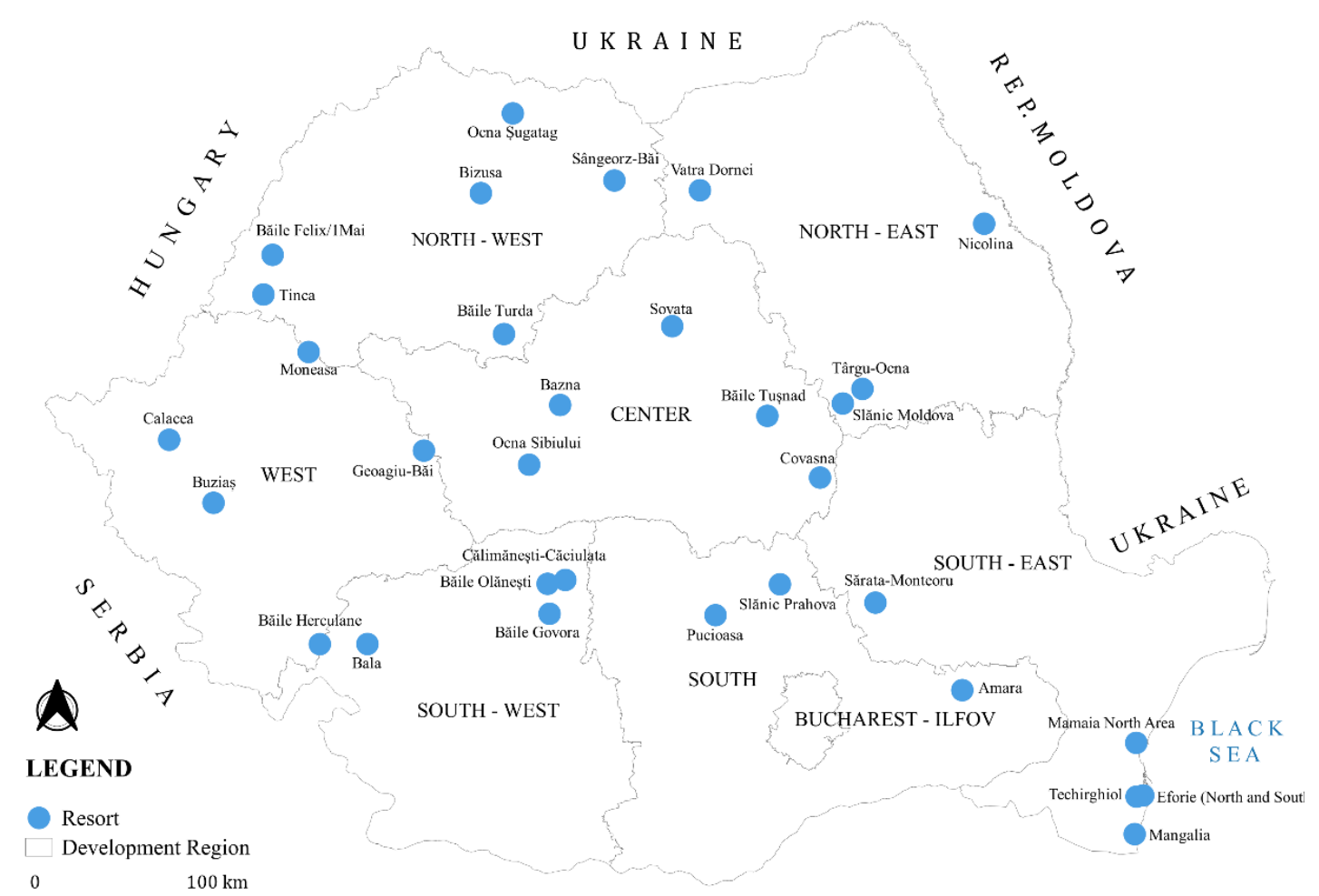

B U L G A R I A

Figure 1. Distribution of spa resorts in Romania 


\section{RESULTS}

In the territorial systems with spa resources from Romania, the total number of employees follows a relatively constant trajectory with some fluctuations during the analyzed period, with an increase of 14,287 employees from 2000 to 2018. Regarding the share of the number of employees in the tourism sector from the total economy, this is between $5.2 \%$ (2012) and 7\% (2004) (Figure 2).

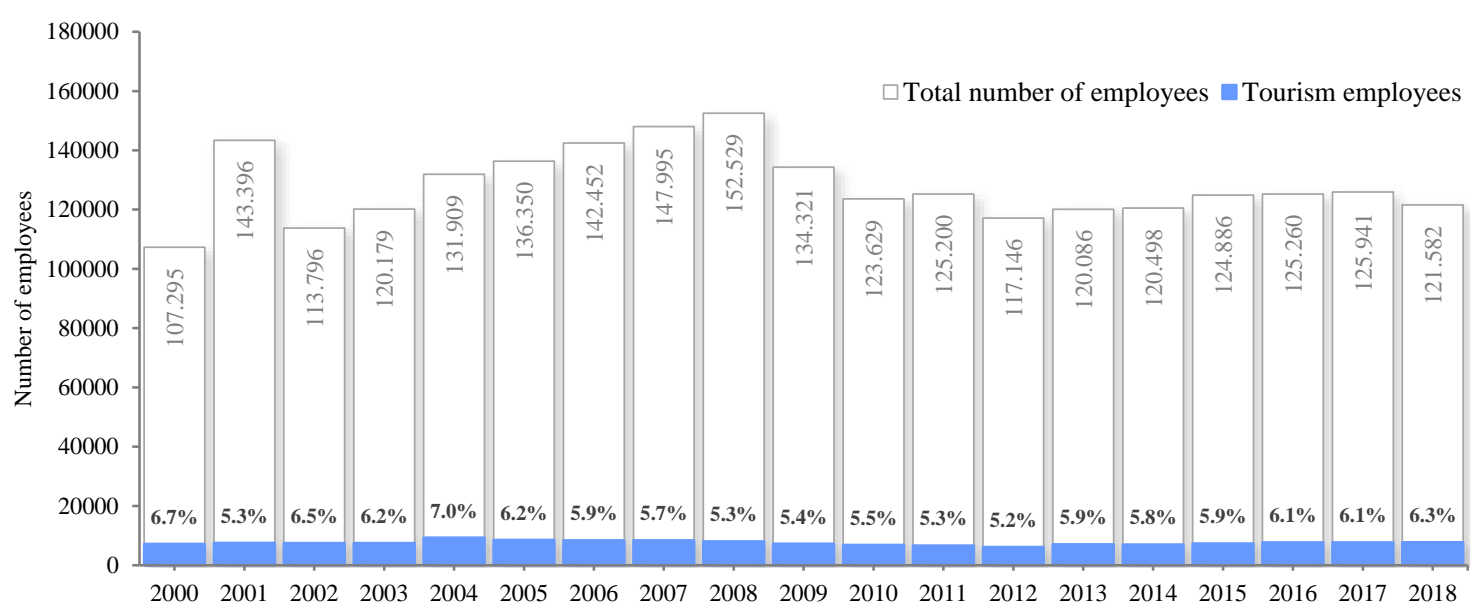

Figure 2. Evolution of the total number of employees and the share of the number of employees from tourism, in spa resorts Source: Project UB 1423

The actual number of employees in tourism is presented under the aspect of a relatively constant evolution, with permanent fluctuations, decreases and increases from year to year (Figure 3). The largest decrease in the entire period analyzed occurred with the global economic crisis, which caused the number of employees to decrease since 2007. Thus, from this year to 2012, their number decreased by up to 2257 employees, the most affected area being that of Hotels and similar accommodation. After this period, the number of employees started to increase slightly, their number in 2018 being 7720, representing $6.3 \%$ of the total number of employees from spa resorts.

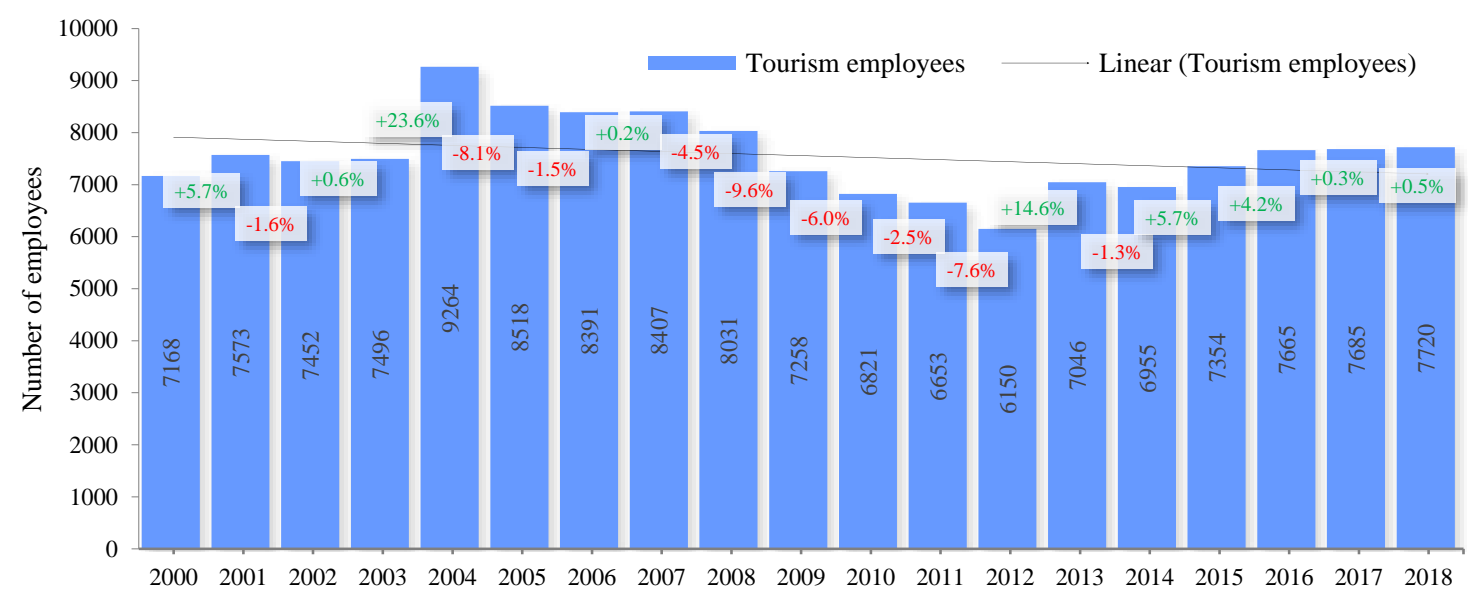

Figure 3. Evolution of the number of employees from tourism, in spa resorts Source: Project UB 1423 
Figure 4 shows the evolution of the number of employees by activity areas, four-digit NACE codes belonging to the tourism sector. Most employees worked in hotels and similar accommodation facilities. The evolution of this indicator is a downward one, the maximum number of employees registering in 2004, when it reached the value of 8611 employees, representing $92 \%$ of the total number of tourism employees.
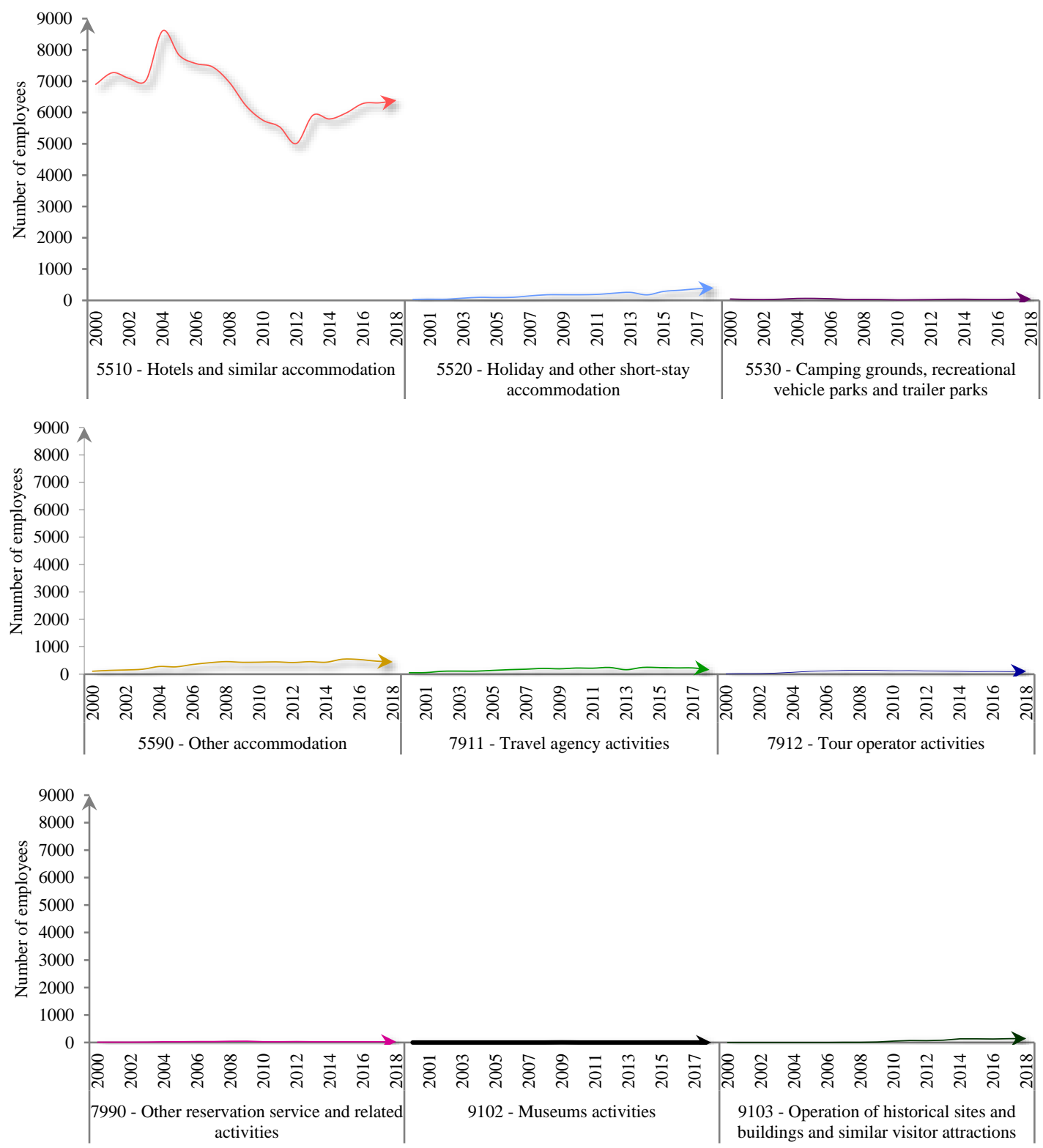

Figure 4. Evolution of the number of employees from tourism by activity sectors Source: Project UB 1423

The second area of activity that registers a significant number of employees is that of Other accommodation services, which from 109 employees in 2000, reaches 448 in 2018. As a percentage, this field holds $7.5 \%$ of the total number of tourism employees in 2015 , when it registered the highest value (549). The field of Holiday and other short-stay accommodation (NACE code 5520), records an ascending trajectory, otherwise, at the end of 2018, there were 394 employees, the highest recorded value, representing from the total number of tourism employees $5.1 \%$. The smallest number of employees were 
registered in the Museums Activities, where out of the 19 years analyzed, 16 registered 0 employees, and the highest value was 4 employees, in 2009, at the level of Nicolina resort. The other tourist activities had a number of employees below the threshold of 250 .

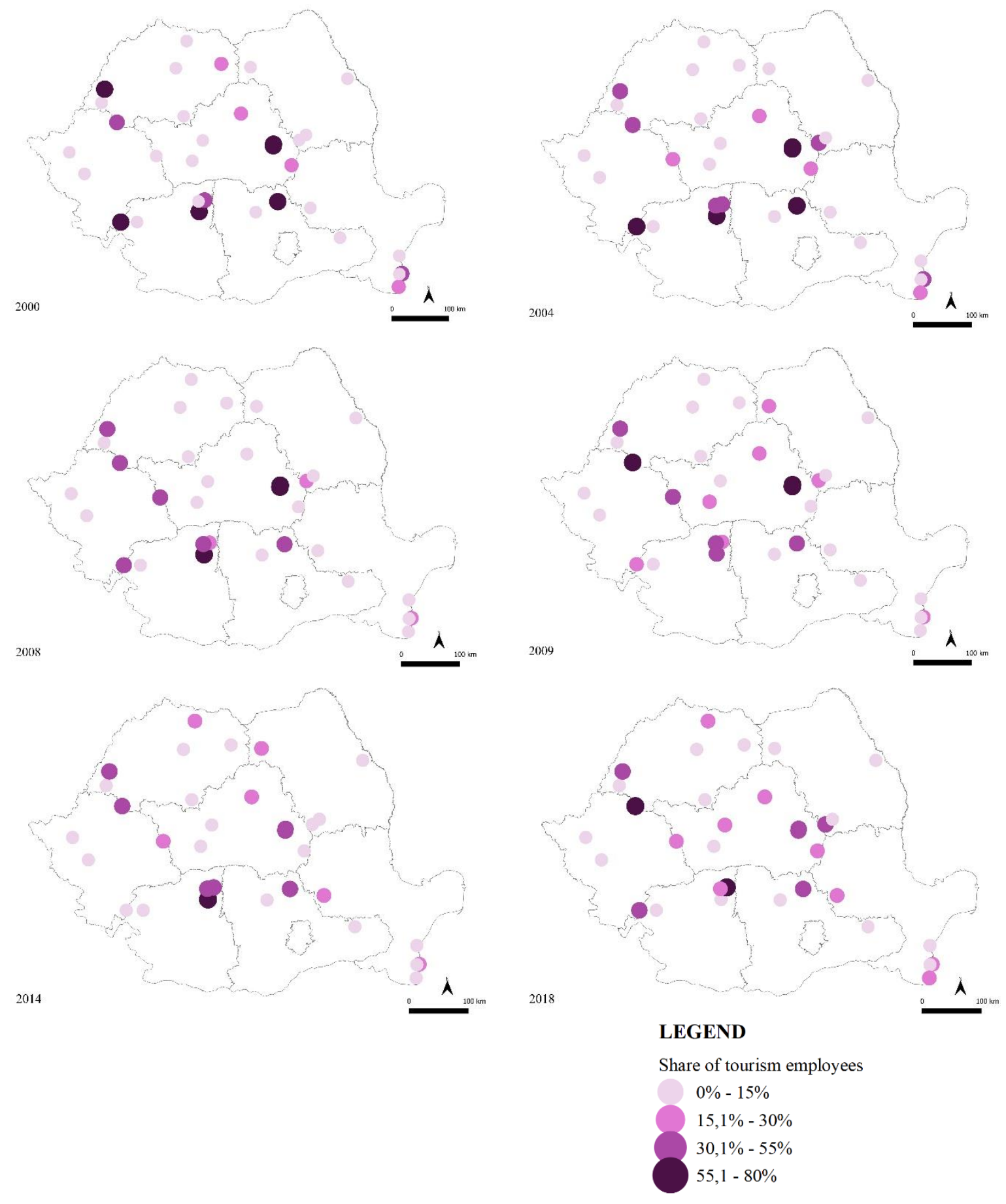

Figure 5. Distribution of the share of the number of tourism employees out of the total number of employees from the Romanian spa resorts, in the years 2000, 2004, 2008, 2009, 2014 and 2018. Source: Project UB 1423

The distribution of the share of the number of employees from the tourism sector (Figure 5 ), shows the evolution of this indicator in the Romanian spa resorts for the years 2000 , 2004, 2008, 2009 (economic crisis period), 2014 and 2018. In the first year of analysis 
most of the resorts (20) were in the category of $0 \%-15 \%$ (Nicolina - treatment base that belongs administratively from the city of Iași, Amara, Slănic Moldova, Târgu-Ocna, Ocna Șugatag, Băile Olănești, Techirghiol etc) and only 5 resorts have a share of tourism employees between 55.1\% and 80\% - Băile Felix (56,3\%), Băile Govora (70,8\%), Băile Herculane $(58,7 \%)$, Băile Tuşnad $(77,2 \%)$ and Slanic Prahova $(67,3 \%)$. As for the category $15.1 \%-30 \%$, there were 4 resorts, and for $30.1 \%-55 \%$ only 3 resorts.

The year 2004 brings changes regarding the shares of the employees. The share of employees for Băile Felix resort decreases, to $49 \%$, but the number of resorts with share between $30.1 \%$ and 55\%, increases from 3 stations, in the previous year, to 6 stations.

In 2008-2009, the only resort that retains its large number of employees in the tourism sector is Băile Tușnad resort, and most of the resorts fall into the first category.

The last two years analysed, place Băile Tușnad resort in the category of resorts with shares below $55 \%$, but it brings high shares for Bălile Călimănești-Căciulata and Moneasa, $59 \%$ and $65 \%$.

\section{CONCLUSIONS}

The results of the study bring an additional in the economic analysis of the spa resorts at the level of Romania (which are 32, according to the Governmental Decision no.926 of 2006), and the chosen methodology leads to a better understanding of how tourism works in terms of the number of employees in each spa resort.

Based on the analysis performed for the number of employees in the tourism sector, there is an increase in the last years of the analysis for this economic indicator, most of them active in the field of activity with the NACE code 5510 - Hotels and similar accommodation, which has over the whole analyzed period, 19 years, over $80 \%$ of the total number of employees from tourism. From the distribution of the share of employees, it turns out that the resorts with the most employees in tourism, over 50\%, were: Băile Tuşnad (2000,2004 2008, 2009), Băile Govora (2000, 2004, 2008, 2014), Slănic Prahova (2000, 2004), Moneasa (2009, 2018) and Băile Herculane (2000 and 2004). For these resorts, tourism is the main sector in their economy.

Most resorts are in the $0 \%-15 \%$ category, which shows that tourism is not the main economic sector, being complementary.

The management strategies can be one of the ways that can lead to maximizing the beneficial effects of the development of the economic activities, entering here those activities that are generated by the development of the tourism sector, provided that the particularities of the local or regional economic system are known [14], [15], [16], [17], [18].

\section{Acknowledgement}

This paper is co-financed from the Human Capital Operational Program 2014-2020, project number POCU / 380/6/13/125245 no. 36482 / 23.05.2019 "Excellence in interdisciplinary $\mathrm{PhD}$ and post- $\mathrm{PhD}$ research, career alternatives through entrepreneurial initiative (EXCIA)", coordinator The Bucharest University of Economic Studies".

\section{REFERENCES}

[1] Garau-Vadell J.B., Gutierrez-Taño D. \& Diaz-Armas R. Economic crisis and residents' perception of the impacts of tourism in mass tourism destinations. J. Destin. Mark. Manag., vol.7, pp 68-75, 2018. 
[2] Grecu A., Gruia A.K., Marin M., Bănuță M., Olteanu C., Constantin I., Gadoiu M., Teodorescu C., Dobrea C.R. \& Drăghici C.C. Specificity of sustainable structural dynamics of local economy in Romanian tourist resort, Sustainability, vol. 11, 2019.

[3] Moscardo G., Konovalov E., Murphy L, Mcgehee N.G. \& Schurmann A. Linking tourism to social capital in destination communities. Journal of Destination Marketing and Management, vol. 6, pp 286-295, 2017.

[4] Drăghici C. C., Diaconu D., Teodorescu C., Pintilii R. D. \& Ciobotaru A. M. Health tourism contribution to the structural dynamics of the territorial systems with tourism functionality, Procedia Environmental Sciences, vol. 32, pp 386-393, 2016.

[5] Global Spa \& Wellness Economy Monitor, 2014

[6] Peptenatu D., Drăghici C., Stoian D., Pintilii R. D., Cercleux A. L., Merciu C. \& Schvab A. Qualitative changes in the entrepreneurial sector in emerging territorial systems - Craiova case study, Acta Geographica Slovenica-Geografski Zbornik, vol. 54, pp 293-304, 2014.

[7] Eugenio-Martín J.L., Martín Morales N. \& Scarpa R. Tourism and Economic Growth in Latin American Countries: A Panel Data Approach, Natural Resources Management, 2004.

[8] Alam M.S. \& Paramati S.R.The dynamic role of tourism investment on tourism development and CO2 emissions, Research Notes and Reports, Annals of Tourism Research, vol. 66, pp 183215, 2017.

[9] Agovino M., Casaccia C., Garofalo A. \& Marchesano K. Tourism and disability in Italy. Limits and opportunities, Tourism Management Perspectives, vol. 23, pp 58-67, 2017.

[10] Daniels M. J., Drogin Rodgers E.B. \& Wiggins B. P. “Travel Tales": An interpretive analysis of constraints and negotiations to pleasure travel as experienced by persons with physical disabilities, Tourism Management, vol. 26, pp 919-930, 2005.

[11] Eichorn V., Miller G. \& Tribe J. Tourism: A site of resistance strategies of individuals with a disability, Annals of Tourism Research, vol. 43, pp 578-600, 2013.

[12] Minnaert L., Maitland R. \& Miller G. Tourism and social policy. The value of social tourism, Annals of Tourism Research, vol. 36, pp 316-334, 2009.

[13] Ozturk Y., Yayli A. \& Yesiltas M. Is the Turkish tourism industry ready for a disabled customer's market? The views of hotel and travel agency managers, Tourism Management, vol. 29, pp 382-389, 2008.

[14] Peptenatu D., Merciu C., Merciu G., Drăghici C. \& Cercleux L. Specific features of environment risk management in emerging territorial structures, Carpathian Journal of Earth and Environmental Sciences, vol. 7, pp 135-143, 2012.

[15] Peptenatu D., Draghici D. \& Merciu C. Characteristics of entrepreneurial profile in some emergent territorial structures in Romania, Actual Problems of Economics, vol. 12, pp 448-458, 2012.

[16] Pintilii R.D., Peptenatu D., Ciobotaru A.M., Toma S.G., Grigore A.M., Drăghici C. C., Dobrea R.C., Simion A.G., Andronache I., Teodorescu C. \& Diaconu D.C. Creative economies in Romania - spatial projections and trends, Bulletin of Geography-Socio-Economic Series, vol. 37, pp 95-108, 2017.

[17] Drăghici C.C., Andronache I., Ahammer H., Peptenatu D., Pintilii R.D., Ciobotaru A.M., Simion A.G., Dobrea R.C., Diaconu D.C., Vişan M.C. \& Papuc R.M. Spatial evolution of forest areas in the northern Carpathian Mountains of Romania, Acta Montanistica Slovaca, vol. 22, pp 95-106, 2017.

[18] Gruia A. K., Dobrea R.C., Simion C.P., Dima C., Grecu A., Hudea O.S., Marin M., Andronache I. \& Peptenatu D. The Use of Sholl and Kolmogorov Complexity Analysis in Researching on the Sustainable Development of Creative Economies in the Development Region of Bucharest-Ilfov, Romania, Sustainability, vol. 11, 2019. 